\title{
Morning, noon, or afternoon: does timing of direct radiation influence the growth of Picea abies seedlings in mountain forests?
}

\author{
Peter BRANG $^{a *}$, Stefanie VON FELTEN ${ }^{\mathrm{a}, \mathrm{b}}$, Sven WAGNER ${ }^{\mathrm{c}}$ \\ a WSL Swiss Federal Institute of Forest, Snow and Landscape Research, Zürcherstrasse 111, 8903 Birmensdorf, Switzerland \\ b Current address: Institute of Environmental Sciences, University of Zurich, Winterthurerstrasse 190, 8057 Zurich, Switzerland \\ c Institut für Waldbau und Forstschutz, Technische Universität Dresden, Pienner Str. 8, 01737 Tharandt, Germany
}

(Received 5 July 2004; accepted 18 May 2005)

\begin{abstract}
We studied the influence of the timing of direct sunlight on the growth of Picea abies seedlings in a field experiment on a northfacing slope in the subalpine zone of the Swiss Alps. Vertical walls were established to expose three-year-old $P$. abies seedlings to direct sunlight at different times of day (morning, noon, afternoon), and to diffuse light only, during two growing seasons. The light treatments were chosen in order to simulate microsites in forest gaps with different orientations. While the light treatments resulted in different daily soil temperature curves, they affected neither average growing season soil temperature nor the frequency of soil temperatures above $10{ }^{\circ} \mathrm{C}$, which are assumed to be particularly beneficial for seedling growth. Final seedling biomass was unaffected by the timing of direct sunlight, but lower for seedlings receiving diffuse light only. These findings suggest that the orientation of slit-shaped gaps in subalpine forests to promote $P$. abies seedling growth is unimportant.
\end{abstract}

gap orientation / seedling growth / time of day of direct radiation / Picea abies / soil temperature

Résumé - Le matin, à midi, ou l'après-midi : le moment du rayonnement direct influence-t-il la croissance des semis de Picea abies en forêt de montagne? Nous avons étudié si le moment du rayonnement direct pendant la journée influençait la croissance des semis de Picea abies. Cette recherche a été réalisée dans un site expérimental en pente exposé au nord dans la zone subalpine des Alpes suisses. Des parois verticales ont été érigées afin d'exposer des semis de $P$. abies de trois ans au rayonnement direct à différents moments de la journée (le matin, à midi, l'après-midi), et au rayonnement diffus seulement, et ceci pendant deux périodes de végétation. Les microstations formées par les traitements d'exposition à la lumière devaient ressembler à des microstations en ouvertures diversement orientées en forêt. Bien que ces traitements aient modifié l'évolution de la température du sol au cours de la journée, ils n'ont influencé ni la température moyenne du sol pendant la période de végétation ni la fréquence des températures du sol supérieures à $10^{\circ} \mathrm{C}$, un niveau supposé être particulièrement bénéfique à la croissance des semis. Le rayonnement direct n'a pas modifié la biomasse finale des semis, mais la biomasse des semis qui ne recevaient que du rayonnement diffus était plus petite. Il résulte de cette étude que l'orientation des ouvertures en fente dans des forêts subalpines n'est pas susceptible d'influencer la croissance des semis de P. abies.

orientation des trouées / croissance des semis / moment de la journée avec rayonnement direct / Picea abies / température du sol

\section{INTRODUCTION}

In the upper montane and subalpine zones of Switzerland, Norway spruce (Picea abies (L.) Karst) is the most abundant tree species. The continuity of the frequently pure stands is of great importance, as they often protect settlements and infrastructure against snow avalanches and rockfall. Since many of these stands are currently 120 to 200 years old $[13,33]$, while their lifespan is about 250-350 years [12], they need regeneration within the next 100 years. Regeneration of these stands, however, is delicate and may require several decades [8, 34].

To induce regeneration on steep-slope protection forests, cutting slit-shaped gaps has often been recommended [10, 11,
20, 27], and has been increasingly practised since about 1990 [47], in particular on north-facing slopes. The gaps allow direct sunlight to warm the rooting zone of the seedlings, which is important for root growth [9] and photosynthesis [17, 18] and thus for successful establishment. These gaps should be oriented obliquely to the contour line of a slope to avoid avalanche formation, while providing for sufficient direct sunlight. Managers can largely influence the time when direct light reaches the forest ground in the gaps by their size, shape and orientation [10]. Therefore, if the timing of sun patches affects seedling growth, this should influence management decisions.

$P$. abies seedlings establishing in small gaps of subalpine forests do not achieve root depths of approximately $5 \mathrm{~cm}$ before

\footnotetext{
* Corresponding author: brang@wsl.ch
} 
their 3rd or 4th year [9]. Soil temperature within this layer limits root growth $[4,16]$, which starts at a temperature of 8 and $12{ }^{\circ} \mathrm{C}$ [42] and increases up to about $20^{\circ} \mathrm{C}[41,42]$. Site factors affecting near-surface soil temperatures are air temperature, direct sunlight, vegetation cover [3,16, 28], snow cover [3], and soil properties such as water content [38].

While direct sunlight (for instance, potential direct radiation during 1-2 h per day in June) has been shown to be essential for successful seedling growth in upper montane and subalpine forests $[9,11,20,21,27,31]$, little is known about whether the time of day of exposure to direct sunlight matters. Bischoff [6] presumed afternoon light to be particularly advantageous under wet-cool conditions (north slopes, oceanic climate), and morning light under moderately cool and dry conditions (south slopes, continental climate), as the latter dries out the soil to a lesser extent. In a field experiment with artificial gap environments, Wayne and Bazzaz [46] investigated the effect of morning (8:50-13:20) versus afternoon (11:40-16:50) sun patches on birch seedling biomass, and found no significant effect of the timing of light incidence. However, this experiment was conducted at about $350 \mathrm{~m}$ above sea level in the temperate zone where temperature is not supposed to be a limiting factor for the growth of many species, including $P$. abies [34]. In contrast, afternoon light seemed more beneficial to $P$. abies seedling growth than morning and noon light on north and south slopes in a sowing experiment in Swiss mountain forests [9].

Not only the amount of radiation, but also its quality, in particular the red:far red ratio, can affect seedling growth $[5,15$, 26, 45]. However, whereas shade intolerant tree species like Pinus radiata show increased height growth under the low red:far red ratios which can occur in closed stands, shade tolerant $P$. abies saplings tend to form an umbrella-like, flatshaped crown [23, 36]. Moreover, the red:far red ratio near the ground seems to be unaffected by a canopy of mature $P$. abies [2]. We did not, therefore, include the red:far red ratio in our study.

By means of a field experiment, we tested the hypothesis that the time of day of exposure to direct sunlight affects upper soil temperature and growth of $P$. abies seedlings on steep north slopes. Under the moist conditions on such slopes, afternoon direct light was hypothesized to be most beneficial because at this time of day the soil has already been warmed up by higher air temperatures [9]. Thus, the addition of direct light in the afternoon should induce a more prolonged shift of soil temperatures into a range favourable for root growth than does direct light in the morning or at noon. In addition, we investigated the strength and time lag of the response of soil temperature to incident direct sunlight.

\section{MATERIALS AND METHODS}

\subsection{Experimental setup}

The experimental site was situated on a north slope in the Calfeisental (Switzerland, $9^{\circ} 18^{\prime} 30^{\prime \prime} / 46^{\circ} 55^{\prime} 15^{\prime \prime}$ '), in the subalpine zone. The site is at $1725 \mathrm{~m}$ above sea level, and has a slope of $50 \%$. Scattered $P$. abies saplings from natural regeneration were present on the site, but about $50 \mathrm{~m}$ higher up only isolated Pinus cembra trees remained. This indicates timberline conditions for $P$. abies, which we considered
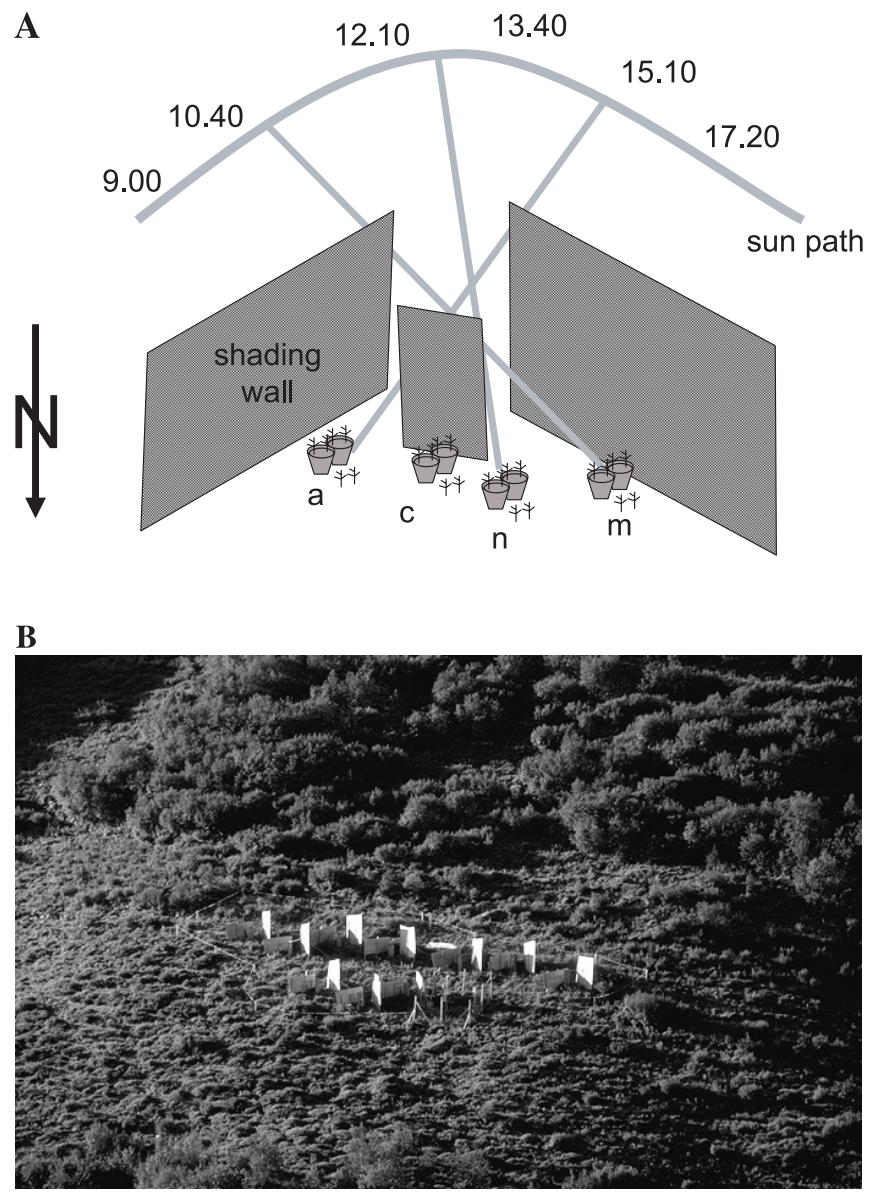

Figure 1. (A) Experimental setup of a single replicate. $a=$ treatment 'afternoon'; c = treatment 'control'; $\mathrm{m}=$ treatment 'morning'; $\mathrm{n}=$ treatment 'noon'. In the field, the pots were actually buried, and the ground surface in the pots was at the same level as outside. (B) View of the experimental site early in the morning. All seedlings, which are planted downslope of the wooden walls, are still in the shadow.

desirable since potential effects of direct sunlight on seedling growth are probably more pronounced on such a cool site than at a warmer site at lower altitudes.

Two-year-old seedlings of $P$. abies from a high altitude provenance (Rüeschegg (Gantrisch), Canton of Fribourg, Switzerland, $1620 \mathrm{~m}$ above sea level, northern aspect) were potted pair-wise in a standard nursery substrate with a light standard long-term fertilization (33 1 Toresa, 81 peat, $90 \mathrm{~g}$ Osmocote Plus, $90 \mathrm{~g}$ horn meal) in April 1999. The round plastic pots ( $20 \mathrm{~cm}$ high, $20 \mathrm{~cm}$ wide) were chosen so as to be large in comparison to seedling size to reduce the risk of drought. We reduced the variation in initial height of the seedlings by discarding very small and very large seedlings. Initial heights were $163.5 \pm 3.2 \mathrm{~mm}$ (mean \pm standard error of the mean, $n=277$ ). Before final transfer to the field site, the seedlings were kept nearby on $1450 \mathrm{~m}$ above sea level for acclimation for one year. At the start of the experiment in July 2000 , the seedlings were three years old.

On the experimental site, vertically placed wooden walls were attached to poles to provide spots with different light exposures (Fig. 1). The walls were $2.5 \mathrm{~m}$ long and $1.3-2.3 \mathrm{~m}$ high. They were erected in summer 2000 and temporarily lain flat during winters to prevent damage from moving snow. The poles were left standing. The 
dates of erecting and taking down the walls were 6-7 July and 25 October in 2000, 11 June and 11 October in 2001, and 30 May and 30 October in 2002. As the upper crowns of the seedlings increasingly received unplanned direct light, the experiment was stopped in autumn 2002. Bud break of trees at this altitude starts around mid June.

The planting spots were selected north (downslope) of the walls using a horizontoscope, an instrument which enables rough estimation of potential duration (without clouding) and timing of direct sunshine in different months $[37,40]$. The four light treatments were: direct sunlight in the morning, at noon and in the afternoon, and only diffuse radiation. These will be referred to as 'morning', 'noon', 'afternoon' and 'control'. The period of exposure to direct sunlight in the three treatments 'morning', 'noon', 'afternoon' was between 1.5 and $3 \mathrm{~h}$ daily and chosen so as to ensure roughly equal amounts of incoming light energy. To avoid heat congestion near the planting spots, a gap of $5-10 \mathrm{~cm}$ was left between the walls and the ground. The 4 treatments described above were replicated 10 times (10 blocks) resulting in a total of 40 planting spots.

Six seedlings were assigned to each of the 40 planting spots, four of them pair-wise in a pot, two planted nearby in the soil (Fig. 1). The resulting split-plot design has 40 main units (the planting spots) and 80 subunits. One subunit contains either 4 seedlings grouped into two pots of two seedlings, or two seedlings outside the pots. Multiple seedlings were planted per subunit in order to avoid missing data as a result of seedling mortality. However, out of the total number of seedlings of $6 \times 4 \times 10=240$, only four seedlings had died from planting by the end of the experiment, each in a different planting spot.

Forty additional seedlings were placed adjacent to the field experiment to provide a second control group receiving full light all day long (further referred to as 'full' treatment). Like the other seedlings, these seedlings were either potted ( 32 seedlings) or outside pots ( 8 seedlings). However, we did not include these seedlings in the statistical analysis since this treatment was not replicated and was thus outside the experimental design. On seedlings that had suffered from frost damage, we clipped multiple stems in order to have trees with a single terminal leader at the beginning of the experiment in summer 2000. This treatment forced seedlings to allocate their resources to only one leading shoot. In each of the four light treatments, 30 to $43 \%$ of the seedlings remained unclipped, on 28 to $40 \%$ one stem was clipped, and on 13 to $20 \%$ two stems were clipped. All seedlings were protected against herbivory with a mesh wire. Herbs and grasses which occurred on the site were left to grow around the seedlings. Their cover averaged $20 \%$ in summer 2001 , while their height was $10-50 \mathrm{~cm}$.

\subsection{Measurements}

Potential direct radiation (for days without any clouding) was estimated using hemispherical photographs taken with a Nikon ${ }^{\circledR} 8 \mathrm{~mm} \mathrm{f} /$ 2.8 lens [29]. Photographs were analysed according to Wagner [43, 44] using a macro based on the Optimas ${ }^{\circledR}$ software (Optimas 6.5.172, Media Cybernetics, Silver Spring, USA). Time resolution of computations for the sun path was 2 min. Potential energy input by direct sunlight (further referred to as direct energy) was calculated for cloudless weather conditions, and the diffuse site factor [44] used as a measure of diffuse radiation.

During the experiment, precipitation, global radiation, air temperature and air humidity were measured continuously using an automated weather station with a data logger (CR10AX, Campbell Scientific, Leicestershire, UK), which was located in the control treatment with full access to direct radiation. In addition, 32 sensors (M-CS505, Campbell Scientific) were used to continuously measure soil temperature at a depth of $4 \mathrm{~cm}$, with a 10 min-interval during summer and a 2 -h interval during winter. Twenty-eight sensors were placed in 3 replications of the seedling experiment, with 6 or 8 sensors attributed to each treatment. Eight sensors were placed outside the pots, but all others were inside pots. Four sensors were installed in the treatment 'full'.
At the end of September 2000 we measured initial height (to the nearest $\mathrm{mm})$ and basal diameter $(0.1 \mathrm{~mm}$, average of two values measured crosswise) of each seedling. After two growing seasons (end of August 2002) these parameters were remeasured, and, in addition, the terminal shoot length in 2002 was recorded $(\mathrm{mm})$. Moreover, we measured the below- and aboveground dry weight of 30 seedlings ( 6 from the four experimental treatments and 6 from the treatment 'full') collected in 2002 in order to estimate the biomass of all experimental plants using the parameters measured.

\subsection{Data analysis}

To test if the light treatments actually did differ as expected, we compared the average daily direct energy input and the diffuse site factors per plot $(n=40)$ among treatments using analysis of variance. A posteriori multiple comparison tests were Bonferroni-corrected. For each treatment, we also compared soil temperatures during the growing season from June to September. We compared temperature averages, and in order to account for situations with satisfactory root growth conditions for the subalpine zone, we calculated the amount of ${ }^{\circ}$ Celsius $\times$ min when soil temperatures exceeded $10^{\circ} \mathrm{C}$. Since some data are missing in 2001, we used only data from 2002 for soil temperature comparisons. Four sensors had to be excluded from the analysis of soil temperatures because they deviated largely from the others in a laboratory test of sensor performance.

Our target parameter for seedling performance was final seedling biomass $\left(\mathrm{B}_{\text {final }}, \mathrm{g}\right)$, which we estimated from the measurements of the excavated seedlings using the following linear regression $\left(n=30, R^{2}=\right.$ $0.9242, p<0.0001)$ :

$\mathrm{B}_{\text {final }}=-4.811+0.232 \times\left(\mathrm{BD}_{\text {final }}\right)^{2}+0.035 \times \mathrm{H}_{\text {final }}-0.073 \times \mathrm{TSL}_{\text {final }}$,

where $\mathrm{BD}$ is the basal diameter $(\mathrm{mm}), \mathrm{H}$ the height $(\mathrm{mm})$ and TSL the terminal shoot length in $2002(\mathrm{~mm})$ of the seedlings. We did not use biomass gain as a target parameter since no data on the basal diameter at the beginning of the experiment were available, and estimating initial biomass with seedling height only and calculating biomass gain as the difference between final und initial biomass resulted in negative values for biomass gain for several seedlings.

Initial height and final biomass values of seedlings in pots on one side, and of those outside pots on the other side, were averaged per subunit $(n=80)$. Final biomass was first square-root transformed and then analysed using a linear mixed effects model. Light treatment and pot were fixed factors, replicate was a random factor, and direct energy, the diffuse site factor and initial seedling height were used as covariates. Two unpotted seedlings, accidentally from the same planting spot, were excluded after an outlier analysis, which reduced the final sample size to $n=79$. The treatment 'full', which was not part of the experimental design, was excluded from the linear mixed effects model.

The time lag between changes in soil temperature and changes in air temperature was calculated in an explorative way by maximizing the fit of a linear regression between soil temperature and air temperature as a function of varying time lags on clear days. The time lag between the exposure to direct sunlight and soil temperature response was determined by comparing graphically the slope changes in soil temperature curves as a function of direct sunlight. Data were analysed using SAS ${ }^{\circledR}$ software (SAS Release 8.02, the SAS Institute Inc., Cary, NC, USA).

\section{RESULTS}

\subsection{Weather conditions}

Monthly mean air temperatures of the nearest weather station of MeteoSwiss (the Swiss federal weather service) in Elm (965 $\mathrm{m}$ above sea level) correlate strongly $\left(R^{2}>0.95\right)$ with our 


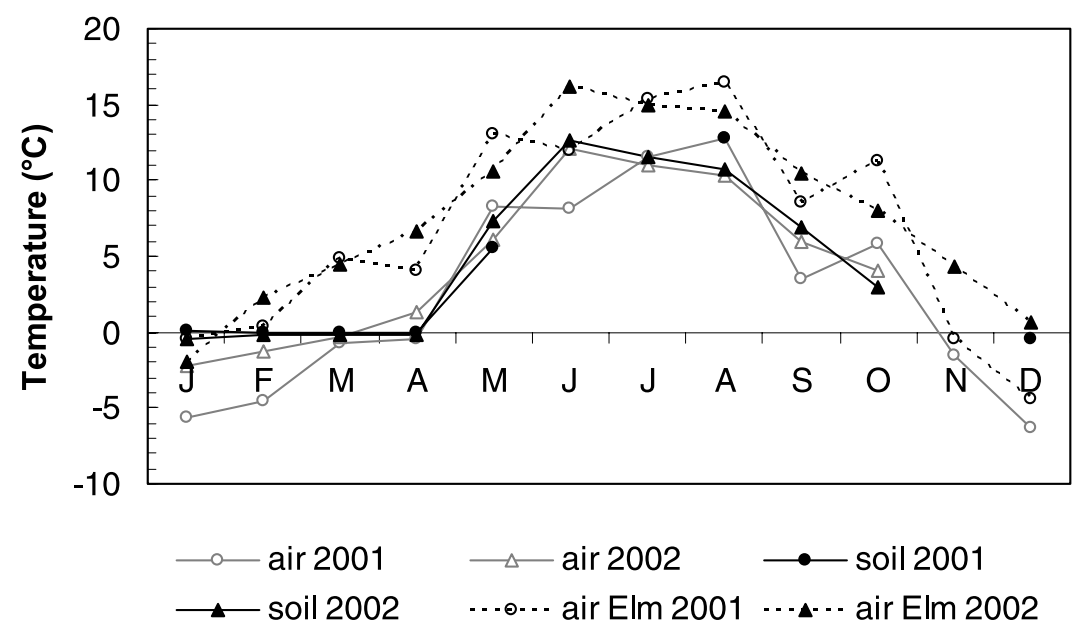

Figure 2. Monthly average soil and air temperatures measured at the field site in the Calfeisental and air temperatures from the weather station in Elm. Soil temperatures measured at a depth of $4 \mathrm{~cm}$.

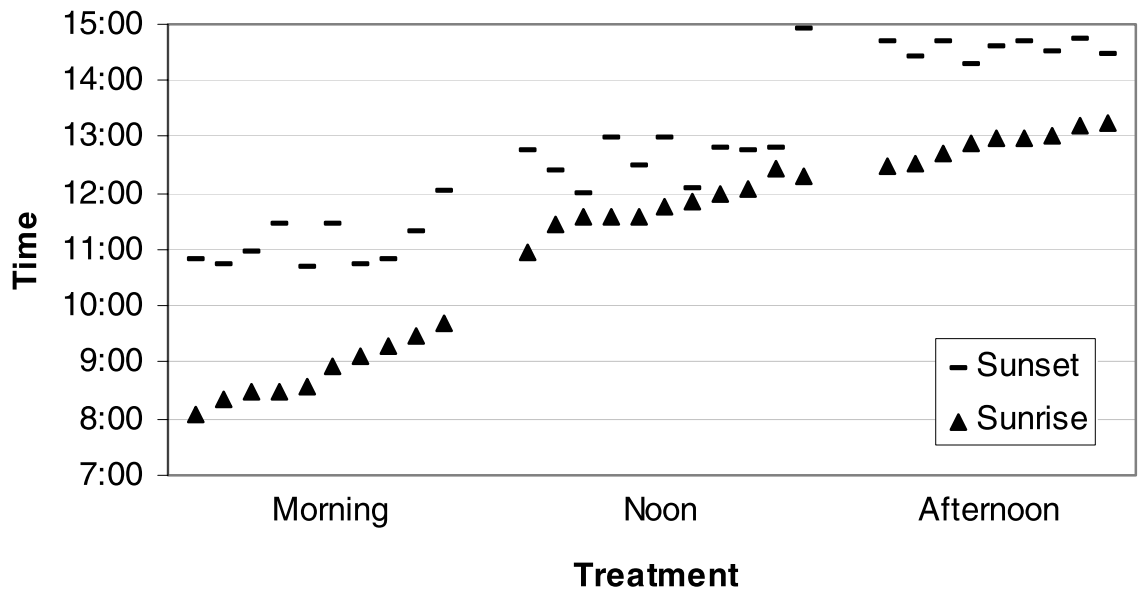

Figure 3. Planned 'sunrises' and 'sunsets' in each of the planting spots in treatments with planned exposure to direct sunlight. Spots in the control treatment are excluded.

in situ measurements for the same period (Fig. 2). Thus, the permanent records from Elm were used to compare temperature and precipitation during the experiment (2001-2002) with long-term means (1959-2002). If the general rise in temperature since the 1950's is taken into account, the mean growing season temperature (June to September) in 2001 was cooler than the expected mean by $-0.6^{\circ} \mathrm{C}$, and the temperatures in 2002 were warmer by $0.4^{\circ} \mathrm{C}$.

\subsection{Performance of sunlight exposure treatments}

The analysis of the hemispherical photographs showed that the artificially created sunrises and sunsets at each planting spot clearly differed in the four treatments (Fig. 3). However, some unplanned 'sunrises' and 'sunsets' occurred (not shown in Fig. 1), especially in the treatment 'noon' and around the summer solstice, since the shading walls were not high enough to completely obscure the sun path. In the treatments 'morning' and 'afternoon' this unplanned exposure of the seedlings to direct sunlight was almost negligible, as unexpected sunflecks occurred mainly early in the morning or late in the evening. In contrast, in the treatments 'noon' and 'control' the input of unplanned direct energy was substantial (Fig. 4). In the treatment 'noon', this was often due to prolonged planned sunflecks (and not additional unplanned sunflecks). In the treatment 'noon', the planned direct energy alone would have been much less than that received in the treatments 'morning' and 'afternoon'. The unplanned direct energy thus made the treatments with direct sunlight more similar with respect to the direct energy received.

The potential energy input of direct sunlight varied according to the type of light treatment (Fig. 4, Tab. I). Inputs were significantly higher in the treatment 'afternoon' than in the treatments 'morning' and 'noon'. Seedlings in the 'control' treatment with no direct planned sunlight obtained significantly less direct energy than those in the other treatments, but clearly more than expected. 


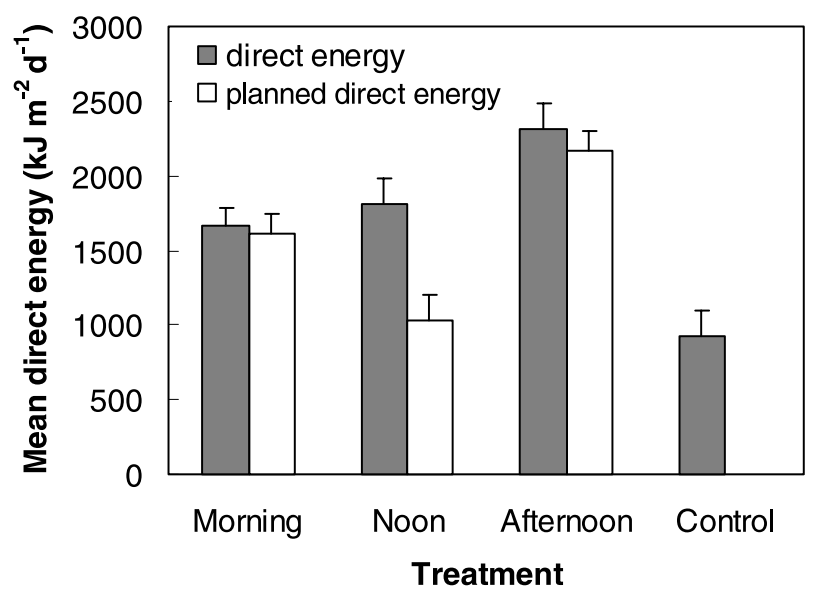

Figure 4. Planned and total (including unplanned) energy inputs (daily averages) from direct sunlight for each treatment. Error bars represent standard errors of means.

Table I. Analysis of variance of mean direct light energy received per plot ( $n=40,10$ in each treatment) and some associated a priori $\left(^{*}\right)$ and a posteriori (**) contrasts, Bonferroni corrected with $\alpha=0.05$.

\begin{tabular}{lcccc}
\hline Source of variance & Num DF Den DF & $F$ & $p$ \\
\hline Light treatment & 3 & 27 & $15.49<0.0001$ \\
$\begin{array}{l}\text { Contrast 'control' vs. other light } \\
\text { treatments }\end{array}$ & 1 & 27 & $35.51<0.0001^{*}$ \\
Contrast 'afternoon' vs. 'morning' & 1 & 27 & $0.0168^{* *}$ \\
Contrast 'afternoon' vs. 'noon' & 1 & 27 & $0.0936^{* *}$ \\
Contrast 'morning' vs. 'noon' & 1 & 27 & $1.0000^{* *}$ \\
\hline
\end{tabular}

The diffuse site factor was $0.80-0.83$ in the 'full' treatment with no shading at all (based on two hemispherical photographs). In the four experimental treatments ( $n=10$ in each), it was higher in the treatments 'control' $(0.53 \pm 0.01$, mean \pm standard error of the mean) and 'noon' $(0.53 \pm 0.02)$ than in the treatments 'afternoon' $(0.45 \pm 0.02)$ and 'morning' $(0.46 \pm 0.01)$. This treatment effect was significant $(p<0.0001$, ANOVA, model not shown).

Differences between treatments in mean soil temperature at a depth of $4 \mathrm{~cm}$ during the growing season 2002 (June-September) were small and their ranking inconsistent between months. All treatments showed an average between 9.1 and $9.3{ }^{\circ} \mathrm{C}$, 'noon' being the warmest treatment followed by 'afternoon' $\left(-0.1^{\circ} \mathrm{C}\right)$, 'morning' and 'control'. In the second control receiving full light, soil temperatures averaged $10.5^{\circ} \mathrm{C}$, and were thus about $1.2^{\circ} \mathrm{C}$ warmer than in the four other treatments. Soil temperatures exceeding $10^{\circ} \mathrm{C}$ were most frequent and pronounced in the 'morning' treatment (in 2002: $42 \%$ of the value of 276 ' $359^{\circ} \mathrm{C}$ min recorded in the "full" treatment), but 'noon' $(39 \%)$ and 'afternoon' (38\%) treatments were very close, and exceedances were clearly higher than in the 'control' treatment
Table II. Linear mixed effects model of seedling biomass by the end of the experiment $(n=79)$. Effects marked with asterisks $(*)$ are random.

\begin{tabular}{|c|c|c|c|c|c|}
\hline Source of variation & Num DF & Den DF & $F$ & $Z$ & $p$ \\
\hline *Replicate & & & & 1.39 & 0.0828 \\
\hline $\begin{array}{l}* \text { Replicate } \times \text { light } \\
\text { treatment }\end{array}$ & & & & 1.48 & 0.0689 \\
\hline \multicolumn{6}{|l|}{ Main plots $(n=40)$} \\
\hline Light treatment & 3 & 59.9 & 3.65 & & 0.0173 \\
\hline $\begin{array}{l}\text { Mean daily radiant } \\
\text { energy }\end{array}$ & 1 & 28.3 & 3.74 & & 0.0631 \\
\hline \multicolumn{6}{|l|}{ Subplots $(n=80)$} \\
\hline Pot & 1 & 34.4 & 24.49 & & $<0.0001$ \\
\hline Initial height & 1 & 58.2 & 173.76 & & $<0.0001$ \\
\hline $\begin{array}{l}\text { Initial height } \times \text { light } \\
\text { treatment }\end{array}$ & 3 & 57.0 & 3.40 & & 0.0238 \\
\hline $\begin{array}{l}\text { Contrast light treatment } \\
\text { 'control' vs. other } \\
\text { treatments (a priori) }\end{array}$ & 1 & 65.2 & 4.79 & & 0.0322 \\
\hline
\end{tabular}

(34\%). Daily temperature amplitudes on July 12, which was selected as an example of a sunny day, were also similar among treatments and ranged between 3 and $4{ }^{\circ} \mathrm{C}$ ( $n=3$ to 6 sensors per treatment). In the treatment with full light, daily amplitudes of the same day were considerably larger $\left(12^{\circ} \mathrm{C}, n=2\right)$. Maximum differences between sensors in the 'full' treatment and sensors with no direct light at a certain time were up to $10^{\circ} \mathrm{C}$.

No differences in the average annual or daily soil temperatures were detected between the root zone inside and outside the pots. In the pots, however, the daily amplitudes of soil temperatures were larger. As a result, the soil temperatures outside the pots exceeded $10^{\circ} \mathrm{C}$ less often than those inside the pots (frequency of exceedances $\sim 91 \%$ of those recorded in the pots).

\subsection{Seedling growth}

After three growing seasons, initial stem height was the most important determinant of seedling biomass (Tab. II). Seedlings that were already tall when planted also had a large biomass at the end of the experiment. This relationship was strongest in the 'control' and weakest in the 'noon' treatment (significant interaction term: Initial height $\times$ Light treatment).

Seedling biomass was significantly affected by the direct sunlight treatments (Tab. II). However, none of the treatments 'morning', 'noon' or 'afternoon' was significantly more beneficial for seedling growth than any other (Fig. 5). The treatment effect was mainly due to the smaller final biomass of seedlings in the 'control' treatment, which was $9.5 \pm 1.2 \mathrm{~g}$ (mean \pm standard error) in comparison to $10.0-11.0 \pm 0.9-1.3 \mathrm{~g}$ in the other treatments. This effect was significant in the mixed effects model (Tab. II, $p=0.0322$ ), although it is barely visible in Figure 5.

Furthermore, the seedlings in pots had significantly larger biomass (mean $10.9 \mathrm{~g}$ ) than those planted directly in the soil (mean $8.7 \mathrm{~g}$ ). There was a marginally significant tendency 


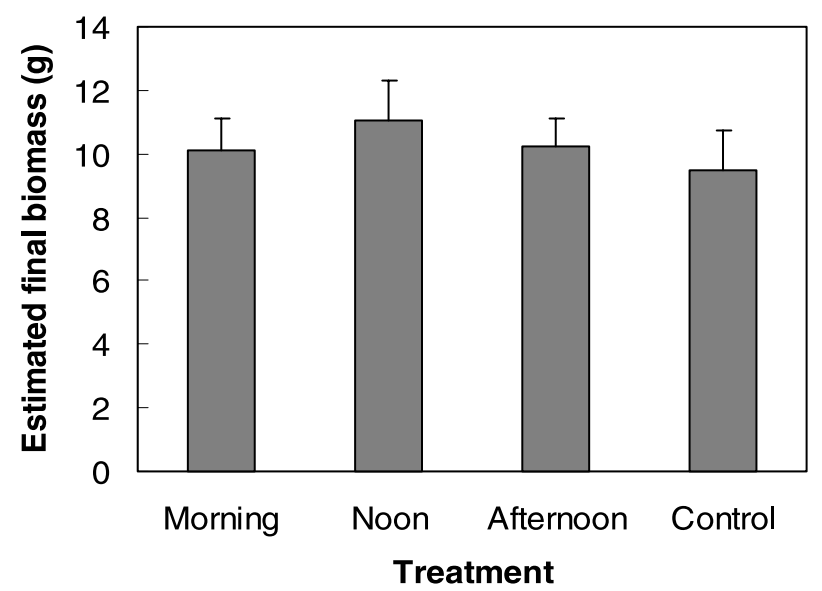

Figure 5. Average final seedling biomass per treatment. Data from seedlings in pots and outside were pooled. Error bars represent standard errors of means.

( $p=0.0631)$ for the mean daily energy input from direct sunlight to negatively affect seedling biomass (parameter estimate for the influence of potential direct energy $\left(\mathrm{kJ} \mathrm{m}^{-2}\right)$ from May to September on biomass: $-0.00025 \times$ direct energy \pm 0.00013 ). This is consistent with the small seedling biomass found in the "full" treatment $(8.5 \pm 1.5 \mathrm{~g}$ in 2002), which is less than the biomass reached in the four experimental treatments (Fig. 5). The seedlings in the 'full' treatment received a daily average of $9.000 \mathrm{~kJ} \mathrm{~m}^{-2}$ potential direct energy input and thus four to ten times as much potential energy as the seedlings in the other four treatments. In contrast to the almost significant effect of direct radiation on seedling biomass, the diffuse site factor was clearly not significant and was therefore eliminated from the linear mixed effects model.

\subsection{Light energy and soil temperature}

Incident direct sunlight affected the soil temperature at a depth of $4 \mathrm{~cm}$ with a time lag of about $40 \mathrm{~min}$, resulting in the different treatments having typical temperature curves. The response of the soil temperature to changes in air temperature, which was derived from regressing soil temperature in the "control' treatment on air temperature using varying time lags for two sensors on clear days, was more lagged, by 3-4 h (Fig. 6, maximum values of the two curves). The best regressions for each of the two sensors, with a time lag of 3 and $4 \mathrm{~h}$, had an $r^{2}$ of 0.95 .

\section{DISCUSSION}

\subsection{Performance of light treatments and effects on soil temperature}

An experiment similar to ours, including the use of shading walls to investigate the impact of the timing of direct sunlight on seedling growth, was used by Wayne and Bazzaz [46] in a temperate forest (Harvard forest, $350 \mathrm{~m}$ above sea level). To our knowledge, however, our study is the first of this kind to be carried out within the subalpine forest zone, where site conditions and limitations are very different from those prevailing in Harvard Forest.

In our experiment, the amount of potential energy from direct sunlight reaching the soil surface was slightly overestimated for two reasons. First, the fish-eye photos were not taken at ground level, but about $12 \mathrm{~cm}$ above ground due to the size



Figure 6. Soil temperature curves on sunny days typical for each treatment, recorded on August 14 in 2001. This day was chosen (instead of July 12) because unplanned direct energy input did not occur any more at this date, which is sufficiently distant from summer solstice. 
of the fish-eye equipment, and second, there was some ground vegetation. This overestimation would have been greater during the times of day when the solar angle was low, i.e. in the 'morning' and 'afternoon' treatments. Nevertheless, soil temperatures did respond to the timing of direct light and thus differed between treatments within the course of one day (Fig. 6), consistent with an earlier study [27]. Moreover, some ground vegetation is usually present in real slit-shaped gaps. In this respect, the environment created in our experiment is close to real forest habitats.

The experimental treatments were successful in mimicking the influence of direct radiation in forest gap environments at different times of day. However, this was less the case with diffuse light. Diffuse site factors $(0.45-0.55)$ exceeded values found in real slit-shaped forest gaps by $50-100 \%$. On a steep north-facing slope, Frehner [21] found diffuse site factors of $0.08-0.40$ in small and some large gaps. On sun-exposed spots in small elongated openings, which our study tried to mimick, values of $0.2-0.3$ seem more realistic. The additional diffuse light may have weakened the effects of direct radiation on seedling growth. It is not clear to what extent the walls created a similar microclimate to that in gaps with respect to air humidity, air temperature and wind speed. We assume that the differences among treatments would have been more pronounced if treatments had been applied more rigorously, i.e. with no unplanned sunlight at all, with more realistic (lower) levels of diffuse radiation, and for a longer time span. Despite these limitations, our experiment clearly mimicked normal exposure to direct radiation at different times of day.

The time lag of 3-4 h between maximum air temperatures and maximum soil temperatures at a depth of $4 \mathrm{~cm}$ in the control treatment is in agreement with a soil temperature model built by Hares and Novak [24, 25]. They measured and simulated soil temperatures on agricultural soils at a depth of 1 and $10 \mathrm{~cm}$ and found that the temperature maximum at $10 \mathrm{~cm}$ depth was approximately $4 \mathrm{~h}$ behind that at $1 \mathrm{~cm}$ depth. If the reference curve is measured in the free air as in our experiment and not at $1 \mathrm{~cm}$ depth, the time lag at $10 \mathrm{~cm}$ depth would amount to a time interval somewhat above $4 \mathrm{~h}$.

Neither the average growing season soil temperatures nor exceedances of $10^{\circ} \mathrm{C}$ varied much among our light treatments. The short energy pulses in the treatments with direct sunlight did not result in higher mean soil temperatures during the whole growing season than in the 'control' treatment. This should be seen in the context of an average clouding of about $60-70 \%$ on the site in the years 2001 and 2002 during summer [14]. The direct energy input in the treatment 'afternoon', which we hypothesized to exhibit the highest soil temperatures, was higher than in the other treatments (Fig. 4). This did not, however, result in higher average soil temperatures during the growing season in this treatment, nor in more frequent and pronounced exceedances of $10{ }^{\circ} \mathrm{C}$. So, not surprisingly, there was also no significant increase in seedling growth.

Even in the treatment 'full', the average seasonal soil temperatures at a depth of $4 \mathrm{~cm}$ exceeded those in the control (without planned direct sunlight) by only about $1.5^{\circ} \mathrm{C}$. At any time of day, the difference between the 'full' and the other treatments did not exceed about $10^{\circ} \mathrm{C}$ (on July 12 in 2001, Fig. 6). Sunlight exposure exceeding four hours daily occurs only exceptionally in small forest gaps on north slopes [9, 10]. For this reason and given the small differences in average soil temperature at $4 \mathrm{~cm}$ depth between treatments (see above), such differences in real gaps are likely to be similar to or even smaller than those found in our experimental treatments. On clear days, Brang ([9], Fig. 24) found, between 10:00 a.m. and 6:00 p.m., maximum differences in average surface temperatures of $2{ }^{\circ} \mathrm{C}$ between microsites receiving different amounts of direct sunlight in small gaps in subalpine $P$. abies forests. In contrast, direct radiation can strongly influence temperatures at the soil surface in high-elevation environments [3], and instantaneous values at $1 \mathrm{~cm}$ depth [27]. These results suggest that, given an intermediate direct energy input, the time of day of exposure to direct light is unlikely to influence the growth of $P$. abies seedlings by a soil temperature-root growth path.

There are other factors that might have more effect on soil temperatures than the timing of direct sunlight. In a field experiment in subalpine forests of south central British Columbia, Coates [16] found that, throughout the snow free period, soil temperatures at $10 \mathrm{~cm}$ depth were about $5{ }^{\circ} \mathrm{C}$ higher in soils where competing vegetation was removed than in soils beneath undisturbed vegetation. Smaller, but still notable differences due to vegetation cover were found in an experiment in Quebec [28]. Alexander [1] and Brang [9] both recorded higher soil surface temperatures on soils with a humus layer than on mineral soils. In the latter case, in gaps on a subalpine north slope, temperature maxima differed by $6{ }^{\circ} \mathrm{C}$.

\subsection{Seedling growth}

Soil temperature has been shown to be a limiting factor for seedling growth in subalpine forests $[3,4,16,41]$, especially under moist conditions $[9,11,27]$. The minor growth of seedlings in the 'control' treatment than in the treatments receiving direct sunlight (Fig. 5) is consistent with earlier studies suggesting $1-2 \mathrm{~h}$ of potential direct sunshine per day to be crucial for seedling growth in subalpine environments [9, 11, 20, 21, $27,31]$. However, our starting hypothesis that exposure to direct light in the afternoon would be most beneficial for seedling growth, since this would result in the most prolonged shift of soil temperature into a zone for satisfactory growth conditions $\left(>10^{\circ} \mathrm{C}\right)$, must be rejected. Neither soil temperatures nor seedling growth were higher in the treatment 'afternoon' than in the other treatments with direct sunlight.

Seedlings in the treatment 'full', where the soil temperatures were highest, showed the lowest biomass gains of all seedlings receiving planned direct sunlight. Thus, seedling growth seems to be influenced by both beneficial effects of direct light on soil temperature and negative effects. Negative effects include potential drought and low temperature photoinhibition. The latter is caused by excess energy under low air temperatures. Egerton et al. [19] have shown that Eucalyptus pauciflora trees benefit from a reduction in irradiance (seedlings sheltered by vertical screens transmitting 50\% incident sunlight) when growth is limited by low temperatures because of low temperature photoinhibition. Similarly, Germino et al. [22] found Picea engelmannii germinants survived better on the north than on the south sides of tree islands. This would be in line with the almost significant negative effect of direct energy that was detected in our experiment. 
In this study, we exposed seedlings to experimental treatments during two complete growing seasons (2001 and 2002). The first application of the treatments in summer 2000, which became effective at the beginning of July only, is unlikely to have influenced seedling growth measured two years later to a large extent. The short two-year period of treatment exposure may have contributed to the small effects found. However, given the small size of the effects after two years of treatment exposure, large effects after longer exposure are unlikely.

Initial height had a highly significant effect on final seedling biomass. This effect has repeatedly been demonstrated, leading to many efforts to eliminate it in experiments $[28,30,32,35$, 39]. It is not surprising that initial height was most influential for seedling biomass in the 'control' treatment (significant interaction: Initial height $\times$ Light treatment), as these seedlings had the poorest growth with the lowest gain in biomass.

A fertilization effect may explain why seedlings in pots grew better than those planted in the soil. The standard fertilizer added to the pots might well have been more nutrient rich than the in situ subalpine soil. Moreover, seedlings planted in the soil may have suffered from transplanting shock [7]. A soil temperature effect (more frequent exceedances of $10{ }^{\circ} \mathrm{C}$ in pots) is a less likely cause of this pattern.

Delucia and Smith [18] found a significant correlation between minimum night temperatures and reductions in photosynthesis in Picea engelmannii at high elevations in the Medicine Bow Mountains of Wyoming (USA). However, we can assume that soil temperature minima at night did not vary between the light treatments applied in our study since all treatments were applied in the open.

\section{CONCLUSIONS}

Our study suggests that, while a certain amount of direct sunlight enhances the growth of $P$. abies seedlings in subalpine environments, the timing of exposure to direct sunlight is less important. The pathways of influence of direct sunlight need further study. We found more evidence for positive than for negative effects of sun patches on seedling growth, but both effects were present. The results of our study do not support a soil temperature-root growth-total biomass gain pathway, which has been previously hypothesized $[11,27]$. Our results suggest that such effects are absent since sun patches of a few hours daily have only a small effect on the average temperature and degree-minutes above $10^{\circ} \mathrm{C}$ in the root zone of seedlings.

Treatment differences found in an experimental setting such as ours have to be very large to be relevant for management since, in real forest habitats of $P$. abies seedlings, sun patches will be less clearly delineated than in experimental gaps, but vary greatly in space and time. While the edges of an opening will create general daily and seasonal sun patch patterns, local edge permeability due to the spatial position of nearby trees will blur these patterns and lead to frequent changes between sun patches and shade on a micro-site [10], regardless of edge orientation. In a management context, this means that the orientation of small forest openings is of minor importance for regeneration performance in subalpine $P$. abies forests on northern aspects, and clearly less important than the effects of competing ground vegetation $[9,27,28]$ and rainfall interception $[9,11]$ as long as the minimum light requirements of the seedlings are met. When designing gap size, shape and orientation in subalpine $P$. abies forests to promote regeneration, decisions should be made on the basis of criteria other than direct sunlight, including ease of timber harvesting, avoidance of avalanche formation (which prohibits cutting gaps parallel to the slope), the presence of micro-sites such as nurse logs which promote regeneration, and the presence of advance regeneration [27].

Acknowledgements: We thank Anton Burkart for providing the seedlings, Gustav Schneiter for advice and help in running a climate station, Hans-Rudolf Roth for his help with the statistical analysis and Pius Schmid and several field assistants for their efforts during field work.

\section{REFERENCES}

[1] Alexander R.R., Natural regeneration of Engelmann spruce after clearcutting in the central Rocky Mountains in relation to environmental factors, USDA For. Serv. Rocky Mountains For. and Range Exp. Station Res. Pap. 254, 1985, 17 p.

[2] Ammer C., Untersuchungen zum Einfluss von Fichtenaltbeständen auf die Entwicklung junger Buchen, Berichte aus der Holz- und Forstwirtschaft, Shaker Verlag, Aachen, 2000.

[3] Aulitzky H., Die Bodentemperaturverhältnisse an einer zentralalpinen Hanglage beiderseits der Waldgrenze. I. Die Bodentemperatur oberhalb der zentralalpinen Waldgrenze, Arch. Meteorol. Geophys. Bioklimatol. B 10 (1961) 445-532.

[4] Aulitzky H., Turner H., Bioklimatische Grundlagen einer standortsgemässen Bewirtschaftung des subalpinen Lärchen-Arvenwaldes, Mitt. Eidgenöss. Anst. Forstl. Vers.wes 58 (1982, 4) 327-580.

[5] Bagnaresi U., Baldini E., Rossi F., Energia radiante, struttura e accrescimento del novellame di abete rosso e di abete bianco in alcune formazioni forestali delle Alpi orientali, Ann. Accad. It. Sci. For. 38 (1989) 81-108.

[6] Bischoff N., Pflege des Gebirgswaldes: Leitfaden für die Begründung und forstliche Nutzung von Gebirgswäldern, Eidgenössische Drucksachen- und Materialzentrale, Bern, 1987.

[7] Blake T.J., Transplanting shock in white spruce; effect of cold-storage and root pruning on water relations and stomatal conditioning, Physiol. Plant. 57 (1983) 210-216.

[8] Brändli U.-B., Zur Verjüngungs- und Wildschadensituation im Gebirgswald der Schweiz: Regionale Ergebnisse des ersten Landesforstinventars (LFI), 1983/1985, Schweiz. Z. Forstwes. 146 (1995) 355-378.

[9] Brang P., Experimentelle Untersuchungen zur Ansamungsökologie der Fichte im zwischenalpinen Gebirgswald, Beiheft Z. Schweiz. Forstver. 77 (1996) 375S.

[10] Brang P., Ansamungsgunst und Verteilung der Direktstrahlung in schlitzförmigen Bestandesöffnungen zwischenalpiner Fichtenwälder, Schweiz. Z. Forstwes. 147 (1996) 761-784.

[11] Brang P., Early seedling establishment of Picea abies in small forest gaps in the Swiss Alps, Can. J. For. Res. 28 (1998) 626-639.

[12] Brang P., Duc P., Zu wenig Verjüngung im Schweizer GebirgsFichtenwald: Nachweis mit einem neuen Modellansatz, Schweiz. Z. Forstwes. 153 (2002) 219-227.

[13] Brassel P., Brändli U.B. (Eds.), Schweizerisches Landesforstinventar: Ergebnisse der Zweitaufnahme 1993-1995, WSL und BUWAL, Verlag Paul Haupt, Berne, Stuttgart, Vienna, 1999.

[14] Bundesamt für Meteorologie und Klimatologie (MeteoSchweiz), Annalen 138 (2001), 139 (2002). 
[15] Clapham D.H., Dormling I., Ekberg I., Eriksson G., Qamaruddin M., VincePrue D., Latitudinal cline of requirement for far-red light for the photoperiodic control of budset and extension growth in Picea abies (Norway spruce), Physiol. Plant. 102 (1998) 71-78.

[16] Coates K.D., Emmingham W.H., Radosevich S.R., Conifer-seedling success and microclimate at different levels of herb and shrub cover in a Rhododendron-Vaccinium-Menziesia community of south central British Columbia, Can. J. For. Res. 21 (1991) 858866.

[17] Day T.A., DeLucia E.H., Smith W.K., Influence of cold soil and snowcover on photosynthesis and leaf conductance in two Rocky Mountains conifers, Oecologia 80 (1989) 546-552.

[18] DeLucia E.H., Smith W.K., Air and soil temperature limitations on photosynthesis in Engelmann spruce during summer, Can. J. For. Res. 17 (1987) 527-533.

[19] Egerton J.J.G., Banks J.C.G., Gibson A., Cunningham R.B., Ball M.C., Facilitation of seedling establishment: Reduction in irradiance enhances winter growth of Eucalyptus pauciflora, Ecology $81(2000)$ 1437-1449.

[20] Frehner M., Beobachtungen zur Einleitung der Naturverjüngung an einem nordexponierten Steilhang im subalpinen Fichtenwald, Schweiz. Z. Forstwes. 140 (1989) 1013-1022.

[21] Frehner M., Untersuchungen über den Einfluss unterschiedlicher Kleinstandorte und der Pflanztechnik auf Fichtenpflanzungen in subalpinen Lawinenschutzwäldern, Beiheft Z. Schweiz. Forstver. 92 (1994)

[22] Germino M.J., Smith W.K., Resor A.C., Conifer seedling distribution and survival in an alpine-treeline ecotone, Plant Ecol. 162 (2002) 157-168.

[23] Greis I., Kellomäki S., Crown structure and stem growth of Norway spruce under varying degrees of shading, Silva Fenn. 15 (1981) 306-322.

[24] Hares M.A., Novak M.D., Simulation of surface energy balance and soil temperature under strip tillage: I. Model Description, Soil Sci. Soc. Am. J. 56 (1992) 22-29.

[25] Hares M.A., Novak M.D., Simulation of surface energy balance and soil temperature under strip tillage: II. Field test, Soil Sci. Soc. Am. J. 56 (1992) 29-36.

[26] Hoddinott J., Scott R., The influence of light quality and carbon dioxide enrichment on the growth and physiology of seedlings of three conifer species. II. Physiological responses, Can. J. Bot. 74 (1996) 391-402.

[27] Imbeck H., Ott E., Verjüngungsökologische Untersuchungen in einem hochstaudenreichen subalpinen Fichtenwald, mit spezieller Berücksichtigung der Schneeablagerung und der Lawinenbildung, Mitt. Eidgenöss. Inst. Schnee- Lawinenforsch. 42 (1987).

[28] Jobidon R., Roy V., Cyr G., Net effect of competing vegetation on selected environmental conditions and performance of four spruce seedling stock sizes after eight years in Quebec (Canada), Ann. For. Sci. 60 (2003) 691-699.

[29] Kunz S., Anwendungsorientierte Kartierung der Besonnung in regionalem Massstab, Geogr. Bern. 19 (1983).
[30] Kuuluvainen T., Hokkanen T.J., Järvinen E., Pukkala T., Factors related to seedling growth in a boreal Scots pine stand: a spatial analysis of a vegetation-soil system, Can. J. For. Res. 23 (1993) 2101-2109.

[31] Lüscher F., Untersuchungen zur Höhenentwicklung der Fichtennaturverjüngung im inneralpinen Gebirgswald, Ph.D. thesis, Professur für Waldbau, ETH Zurich, 1990.

[32] Mitchell A.K., Dunsworth B.G., Bown T., Moran J.A., Aboveground biomass predicts growth limitation in amabilis fir and western hemlock seedlings, For. Chron. 79 (2003) 285-290.

[33] Ott E., Wie ist die Frage der Überalterung für unsere Schweizer Gebirgswälder zu beurteilen? Schweiz. Z. For. 136 (1985) 931944.

[34] Ott E., Frehner M., Frey H.-U., Lüscher P., Gebirgsnadelwälder: Ein praxisorientierter Leitfaden für eine standortgerechte Waldbehandlung, Verlag Paul Haupt, Berne, Stuttgart, Vienna, 1997.

[35] Pacala S.W., Canham C.D., Silander J.A. Jr., Kobe R.K., Sapling growth as a function of resources in a north temperate forest, Can. J. For. Res. 24 (1994) 2172-2183.

[36] Pöntynen V., Tutkimuksia kuusen esiintymisestä alikasvoksina Raja-Karjalan valtionmailla, Acta For. Fenn. 35 (1929) 1-235.

[37] Schütz J.-P., Brang P., L'horizontoscope : un étonnant outil pratique de sylviculture, notamment en haute-montagne, ONF, Bull. Techn. 28 (1995).

[38] Stathers R.J., Spittlehouse D.L., Forest Soil Temperature Manual, FRDA Report, Forestry Canada and British Columbia Ministry of Forests, For. Resource Dev. Agreement 130 (1990).

[39] Thomas S.C., Weiner J., Including competitive asymmetry in measures of local interference in plant populations, Oecologia 80 (1959) 349-355.

[40] Tonne F., Besser bauen mit Besonnungs- und Tageslichtplanung, K. Hofmann, Schorndorf/Stuttgart, 1954.

[41] Tranquillini W., Physiological ecology of the timberline, Springer, New York, 1979.

[42] Vapaavuori E.M., Rikala R., Ryyppö A., Effects of root temperature on growth and photosynthesis in conifer seedlings during shoot elongation, Tree Physiol. 10 (1992) 217-230.

[43] Wagner S., Calibration of grey values of hemispherical photographs for image analysis, Agric. For. Meteorol. 90 (1998) 103117.

[44] Wagner S., Relative radiance measurements and zenith angle dependent segmentation in hemispherical photography, Agric. For. Meteorol. 107 (2001) 103-115.

[45] Warrington I.J., Rook D.A, Morgan D.C., Turnbull H.L., The influence of simulated shadelight and daylight on growth, development and photosynthesis of Pinus radiata, Agathis australis and Dacrydium cupressinum, Plant Cell Environ. 11 (1988) 343-356.

[46] Wayne P., Bazzaz F.A., Morning vs. afternoon sun patches in experimental forest gaps: consequences of temporal incongruency to birch regeneration, Oecologia 94 (1993) 235-243.

[47] Wunder J., Brang P., Fichtenverjüngung im Gebirgswald: Erfolgskontrolle in Schlitzen, Wald Holz 84/6 (2003) 13-14. 